Науковий вісник Львівського національного університету ветеринарної медицини та біотехнологій імені С.З. Гжицького

Scientific Messenger of Lviv National University of Veterinary Medicine and Biotechnologies

doi:10.15421/nvlvet8106

ISSN 2519-2701 print

ISSN 2518-1327 online

$\underline{\text { http://nvlvet.com.ua/ }}$

УДК 338.532.42

\title{
Удосконалення інформаційного середовища розвитку сільськогосподарських підприємств
}

\author{
Л.П. Петришин \\ lydkar@ukr.net \\ Львівський наџіональний аграрний університет, \\ вул. Володимира Великого, 1, Дубляни, Львівська обл., 80381, Украӥна
}

\begin{abstract}
У статті розглянуто питання удосконалення інформачійного середовища розвитку сільськогосподарських підприємств. Робиться висновок про недостатній рівень їхнього інформаційного забезпечення. Наведено окремі елементи досвіду зарубіжсих краӥн у сфері надання інформачійних послуг фермерам. Відзначається, щяо в сучасних умовах інформаційні технології є одним з основних чинників підвищення ефективності та конкурентоспроможності сільськогосподарських підприємств. Уже в найближчій перспективі вони стануть чи не основним виробничим ресурсом для розвитку галузі сільського господарства. Зроблено висновок про те, що результатом нової технологічної революиії стане так зване «точне сільське господарство». У рослинничтві це означає, щчо сільськогосподарські культури будуть вирощуватися за технологіями, які максимально забезпечуватимуть оптимальні умови їх розвитку, збирання, транспортування, зберігання.

Проведено короткий екскурс сторінками найпопулярніших спеціалізованих сайтів, призначених для сільськогосподарських виробників. Відзначено основні їхні позитивні сторони та недоліки. Наголошується на необхідності підвищити роль Міністерства агарної політики і продовольства, Державної служби статистики та вищих навчальних закладів аграрного профілю в покращенні інформаційного забезпечення сільськогосподарських підприємств. Обтрунтовано пріоритетні завдання системи інформачійного забезпечення АПК та визначено основні складові інформачійного забезпечення сільськогосподарських підприємств прогностично-аналітичного характеру. Наголошується, що ефективне функиіонування сучасного інформаційного забезпечення сільськогосподарських підприємств можливе лише в умовах значного покращення технологій мобільного зв'язку у краӥні. Зокрема, впровадження 5 G зв'язку призведе до революиійних змін у бізнес-процесах. У сільському господарстві стане можливим широке використання дронів, роботів, запровадження онлайн-моніторингу полів та тварин. Як результат - запроваджуватимуться нові технології виробництва продукиії рослинництва і тваринництва, нові стандарти ї̈ якості та властивостей. Сільськогосподарські підприємства адаптовуватимуться до ииих змін, на щэо спрямовуватиметься їх видозмінена економічна поведінка.
\end{abstract}

Ключові слова: сільськогосподарські підприємства, інформачійне забезпечення, мобільний зв'язок, точне сільське господарство.

\section{Совершенствование информационной среды развития сельскохозяйственных предприятий}

\author{
Л.П. Петришин \\ lydkar@ukr.net
}

\begin{abstract}
Львовский национальный аграрный университет,
ул. Владимира Великого, 1, г. Дубляны, Львовская обл., 80381, Украина
\end{abstract}

В статье рассмотрены вопросы совершенствования информационной среды развития сельскохозяйственных предприятий. Делается вывод о недостаточном уровне их информационного обеспечения. Приведены отдельные элементы опыта зарубежных стран в сфере предоставления информационных услуг фермерам. Отмечается, что в современных условиях 
информационные технологии являются одним из основных факторов повышения эффективности и конкурентоспособности сельскохозяйственных предприятий. Уже в ближайшей перспективе они станут едва ли не основньм производственным ресурсом для развития отрасли сельского хозяйства. Сделан вывод о том, что результатом новой технологической революичи станет так называемое «точное сельское хозяйство». В растениеводстве это означает, что сельскохозяйственные культуры будут выращиваться по технологиям, которые максимально обеспечат оптимальные условия их развития, сбора, транспортировки, хранения.

Проведен краткий экскурс по страницам самых популярных специализированных сайтов, предназначенных для сельскохозяйственных производителей. Отмечено основные их положительные стороны и недостатки. Подчеркивается необходимость повысить роль Министерства аграрной политики и продовольствия, Государственной службь статистики и высших учебных заведений аграрного профиля в улучшении информационного обеспечения сельскохозяйственных предприятий. Обоснованы приоритетные задачи системы информачионного обеспечения АПК и определены основные составляющие информационного обеспечения сельскохозяйственных предприятий прогнозно-аналитического характера. Отмечается, что эффективное функиионирование современного информационного обеспечения сельскохозяйственньх предприятий возможно лишь в условиях значительного улучшения технологий мобильной связи в стране. $B$ частности, внедрение 5 G связи приведет к револючионным изменениям в бизнес-процессах. В сельском хозяйстве станет возможным иирокое использование дронов, роботов, введение онлайн-мониторинга полей и животных. Как результат - будут вводиться новые технологии производства продукции растениеводства и животноводства, новые стандарты ее качества и свойств. Сельскохозяйственные предприятия адаптируются к этим изменениям, на что будет направлено их видоизмененное экономическое поведение.

Ключевые слова: сельскохозяйственные предприятия, информачионное обеспечение, мобильная связь, точное сельское хозяйство.

\title{
Improvement of informational environment of agricultural enterprises development
}

\author{
L.P. Petryshyn \\ lydkar@ukr.net \\ Lviv National Agrarian University, \\ Volodymyr Velykyi Str., 1, Dubliany, Lviv, 80381, Ukraine
}

\begin{abstract}
The article studies the issue of improvement of informational environment of agricultural enterprises development. The author makes conclusion about insufficient level of their informational support. The research presents some elements of foreign experience in the field of supply of informational services for farmers. It is stressed, that under current conditions, informational technologies are one of the main factors for improvement of efficiency and competitive capacity of agricultural enterprises. In the nearest future, they are going to become the main production resource for agriculture development. The article argues that new technological revolution will result in so-called «accurate agriculture». In crop production, it means that agricultural crops will be grown according to the technologies, which supply maximum optimal conditions of their development, harvesting, transportation, storage.

The work makes a short review of the most popular specialized sites for agricultural producers and marks their positive sides and drawbacks. The author stresses necessity to intensify role of the Ministry of Agrarian Policy and Food, State Office of Statistics and agrarian higher educational establishments in improvement of informational support for agricultural enterprises.

The article determines priority tasks of the system of informational support of AIC and defines main components of informational support for agricultural enterprises of forecast-analytic character. It is confirmed that efficient performance of modern information support for agricultural enterprises is possible only under conditions of substantial improvement of the technologies of mobile communication in the country. Particularly, introduction of $5 \mathrm{G}$ connection will force crucial changes in business processes. In agriculture, it will be possible to use pilotless aircrafts, robots, introduce on-line monitoring of fields and animals. Finally, new technologies of crop production and animal breeding, as well as new standards of product quality and characteristics will be introduced. Agricultural enterprises will adopt to the changes, supporting transformation of their economic behavior.
\end{abstract}

Key words: agricultural enterprises, informational support, mobile communication, accurate agriculture.

\section{Вступ}

Дані про зміни в зовнішньому середовищі сільськогосподарських підприємств надходять до їх власників і керівників у вигляді інформації. Основними вимогами, які ставляться перед інформацією, є іiі повнота, корисність, об'єктивність, суттєвість, своєчасність, достовірність, оперативність, аналітичність, порівнянність та доступність. Прийняття управлінських рішень про зміни в економічній поведінці сільськогосподарських підприємств може базуватися виключно на якісній інформації про внутрішне й зовнішнє середовище. Якщо існуючі вимоги до інформації не виконуються, важко собі уявити процес прийняття оптимальних управлінських рішень.
Більшість сільськогосподарських підприємств в нашій країні, на жаль, позбавлені доступу до необхідної за обсягом і структурою інформації. Це викликане не лише недоліками в розвитку інформаційних технологій, а й у несистемному характері іï збору, обробки та аналізу.

Аналіз досліджень проблеми. Проблема удосконалення інформаційного середовища розвитку сільськогосподарських підприємств стала предметом дослідження багатьох вітчизняних науковців. Серед них варто відмітити праці Дякової Т.А. (Dyakova, 2017), Лапіна A.B. (Lapin, 2015), Харченко B.B. та Онищук В.P. (Kharchenko and Onyshchuk, 2013), Швиденко O.M. (Shvy`denko, 2013) та ін. В них відображено основні аспекти досліджуваної проблеми. Однак поза 
увагою залишилися такі питання, як системність інформаційного забезпечення підприємств, його адаптація до розвитку сучасних інформаційних технологій.

Mета статmi - обгрунтування основних напрямів удосконалення інформаційного забезпечення сільськогосподарських підприємств 3 урахуванням постійного розвитку інформаційного середовища та можливостей сучасних інформаційних технологій.

Виклад основного матеріалу з обтрунтуванням отриманих результатів дослідження. Порівняння інформаційного забезпечення вітчизняних сільськогосподарських підприємств 3 фермерами розвинутих країн світу показуе його значне відставання. Харченко В.В. та Онищук В.Р. зазначили, що «необхідним $є$ запровадження в аграрних підприємствах таких служб, як цінового моніторингу, прогнозноаналітичних центрів, інформаційних центрів. Це дасть можливість суб'єктам господарювання володіти достовірною інформацією щодо системи цінового моніторингу аграрного ринку, прогнозування попиту на сільськогосподарську продукцію на вітчизняному та світовому ринках, системи оптової та оптовороздрібної торгівлі сільськогосподарською продукцією тощо» (Kharchenko and Onyshchuk, 2013).

Американські фермери мають можливість отримувати своєчасну і якісну інформацію, яка $є$ важливою для них, з багатьох спеціалізованих сайтів, RSSканалів. Вона цільово постачається їм на комп'ютери чи на мобільні телефони. Через різноманітні спеціалізовані чати вони мають можливість спілкуватися зі своїми колегами у кіберпросторі. Вони можуть, використовуючи здатності електронного маркетингу, ефективно реалізовувати вироблену продукцію та купувати необхідні матеріально-технічні засоби, підвищувати рівень своїх фахових знань, планувати витрати виробництва й величину доходів, проводити аналіз ефективності здійснених інвестицій тощо.

Використовуючи можливості інформаційних мереж, вони мають можливості програмувати урожайність сільськогосподарських культур та показники продуктивності тварин. Швиденко О.М. цікавим вважає «приклад діяльності сайту infarmservice.com єдиної комп'ютерної програми адміністрування для фермерів, яка постійно перебуває у зв'язку з останніми технологіями Internet-хмартегів». Легка у користуванні та мобільна, ця система забезпечує фермерів найкращим інструментарієм для планування, аналізу, зміни результатів, ведення польових записів, урахування інформації про продажі та витрати, що водночас дає змогу здійснювати детальний бізнесаналіз і допомагає максимізувати фінансові показники» (Shvy`denko, 2013).

В сучасних умовах інформаційні технології $є$ одним з основних чинників підвищення ефективності та конкурентоспроможності сільського господарства. Але вже в найближчій перспективі вони, за прогнозами вчених, перетворяться чи не в основний виробничий ресурс для розвитку галузі. Якщо так звана «зелена революція» базувалася насамперед на фундаментальних змінах у використовуваній в галузі техніці (40-50-і роки минулого століття), а наступна револю- ція - на досягненнях генної інженерії (кінець XX-го початок XXI століття), то майбутня аграрна революція, яка вже розпочалася, базуватиметься на якнайширшому впровадженні інформаційних технологій в сільськогосподарське виробництво.

Результатом нової технологічної революції стане так зване «точне сільське господарство». У рослинництві це означає, що сільськогосподарські культури будуть вирощуватися за технологіями, які максимально забезпечуватимуть оптимальні умови їхнього розвитку, збирання, транспортування, зберігання. Вже в найближчі роки на полях в сільськогосподарських підприємствах працюватимуть дистанційно керовані трактори, інформаційні системи яких дозволять диференціювати технологічні операції (оранку, удобрення, внесення пестицидів) відповідно до особливостей конкретних земельних ділянок, стану сільськогосподарських культур. Ці трактори на основі обробки даних, які поступатимуть 3 сенсорних датчиків, розміщених на земельних ділянках, зможуть мінімізувати втрати врожаю, які навіть у найбільш технологічних господарствах є досить значними.

Датчики забезпечать також раннє виявлення на посівах сільськогосподарських культур та в садах $\mathrm{i}$ ягідниках різноманітних шкідників, хвороб і бур'янів. Залежно від ступеня поширення на конкретних земельних ділянках регулюватиметься доза й концентрація засобів захисту рослин. У тваринництві так само «точне сільське господарство» буде зводитися до якомога повнішого врахування потреб вирощуваної худоби в умовах утримання, боротьбі з захворюваннями тощо. Як і в рослинництві, це забезпечить значне зростання продуктивності.

Можливості впровадження сучасних досягнень інформаційних технологій в сільськогосподарське виробництво надзвичайно широкі. Прикладом цього $€$ результати проведеного в лютому 2016 р. Всеукраїнського хакатону аграрних інновацій, до якого було залучено 25 команд (150 учасників), програмістів, дизайнерів та аграрників, що виборювали три грошові призи, поїздку в Кремнієву долину та перспективи впровадження їхніх розробок у виробництво. Хоча кожній $з$ команд було виділено лише 72 години для розробки інновації, всі вони видали доволі цінні продукти. За підсумками хакатону були виділені «найбільш перспективні види інформаційних послуг в сільському господарстві: електронні карти полів та електронний облік земельного банку, облік паїв (GISсистеми); супутниковий моніторинг полів і використання дронів та безпілотників для агроінспектування; системи передбачення погоди, метеостанції та погодні сервіси; моделювання розвитку хвороб та шкідників; моніторинг внутрішнього середовища для теплиць, складів, корівників; польові сенсори та інша телеметрія; довідники за захворюваннями, шкідниками, породами, сортами, гібридами, добривами, пестицидами, облік; електронний документообіг, бухгалтерські та інші сервіси (облік робочого часу, ресурсів, матеріалів); системи управління взаємовідносин 3 клієнтами та партнерами (CRM)».

Крім названих вище, спеціалісти виділяють також інші види інформаційних послуг, які вже набули по- 
ширення, але вдосконалюватимуться в майбутньому. Це мобільні додатки, які через смартфони надаватимуть фермерам дорадницькі послуги в онлайнрежимі. Радіочастотна ідентифікація тварин дозволить фермерам отримувати детальну інформацію про стан і розвиток кожної з наявних у господарстві. Безпроводні технології забезпечать якісний зв'язок 3 фермерами і усіма об'єктами і суб'єктами, з якими вони мають справи у процесі здійснення господарської діяльності. Автоматизація процесів забезпечить проведення більшості господарських виробничих операцій без прямої участі фермера чи працівників сільськогосподарських підприємств.

Процес інформатизації підприємства є складним. Виникає необхідність його узгодження 3 особливостями використовуваних в ньому технологій. Як вважає Дякова Т.А., «одним з варіантів вирішення цієї задачі є корпоративний інформаційний портал - iнформаційна система підприємства, що здійснює управління іiі інформаційними потоками, виконує функції презентаційного і комунікативного характеру i реалізована за допомогою WEB-технологій. Корпоративний інформаційний портал включає потужні інтерактивні інструменти для взаємодії співробітників, партнерів, клієнтів, для проведення багатьох технологічних операцій у віддаленому режимі» (Dyakova, 2017).

Однією з головних вимог до інформаційного забезпечення підприємства $\epsilon$ його здатність до модернізації. Зміни в діяльності підприємства повинні адекватно відображатися в функціонуванні його інформаційної системи. Не можна не погодитися з думкою Лапіна А.В., що «стабільність, стійкість, ефективність діяльності економічної системи, удосконалення іiі організаційної структури пов'язано з принципом адаптації до зовнішнього середовища. Реалізувати адаптовану систему можна модифікацією інформаційного контуру способом введення моделі регулювання (адаптації). Ця модель повинна у визначений термін забезпечити прогнозування результатів діяльності об'єкта управління в умовах зміни зовнішнього середовища» (Lapin, 2015).

Величезні інформаційні потоки про стан внутрішнього і зовнішнього середовища сільськогосподарських підприємств необхідно впорядковувати, структуризувати, відбирати найважливіші та піддавати їх обробці й аналізу. Уся необхідна інформація повинна бути доступною у зручній і зрозумілій формі, оскільки на іiї основі слід приймати ефективні управлінські рішення, нерідко миттєві. Це вимагає налагодження сучасних систем інформаційного забезпечення сільськогосподарських підприємств.

У 2010 р. спеціалістами Міністерства сільського господарства і продовольства України була розроблена «Стратегія розвитку інформаційного забезпечення АПК і сільського населення України до 2015 р.». У преамбулі до неї наголошується, що поточний стан цієї системи не відповідає сучасним вимогам. У зв'язку з цим «головною метою Стратегії розвитку інформаційного забезпечення АПК і сільського населення України є створення необхідних передумов для формування i розвитку аграрного інформаційного простору, які б могли задовольнити інформаційні потреби сільського населення, виробників та переробників сільськогосподарської продукції, підтримуючих АПК галузей, органів державної влади та неурядових організацій, установ аграрної освіти i науки. Основою досягнення цієї мети є створення Національної системи сільськогосподарської інформації і знань (НССІ3) зі створенням умов, засобів та технологій для підтримки сталого розвитку сільських територій, підвищення якості життя сільського населення, сталого розвитку сільськогосподарського виробництва і розширення можливостей учасників аграрного ринку України». Складовими частинами Стратегії стали пріоритетні задачі, очікувані результати, визначена роль органів державної влади, навчальних закладів та приватних структур в іiї реалізації.

Опираючись на розробки Міністерства щодо пріоритетних задач Стратегії, обгрунтуємо власне бачення. Результати напрацювань автора відображено на рис. 1.

Систему інформаційного забезпечення підприємств АПК поділяють на підсистеми збору інформації та підсистему іiі аналізу й розробки на основі його результатів прогнозів для підприємств, органів державного управління загальнонаціонального та регіонального рівнів, органів місцевого самоврядування тощо. Підсистема прогнозноаналітичного забезпечення сільськогосподарських підприємств для них значно важливіша від системи збору інформації, однак забезпечити ефективне функціонування першої без другої неможливо. Детальніше склад інформаційного забезпечення сільськогосподарських підприємств прогностичного характеру відображено на рис. 2. Його вдосконалення повинно спрямовуватися на досягнення позитивних зрушень в усіх складових.

Керівники сільськогосподарських підприємств, фермери, власники особистих селянських господарств, маючи доступ до задекларованої системи інформаційного забезпечення, основні складові якої відображено на рис. 2, повинні швидко відшукати необхідну інформацію, потреба в якій виникає чи не щоденно у процесі здійснення ними господарської діяльності. Для цього їм повинно було би достатньо зайти до спеціалізованого сайту чи звернутися до дорадчої служби.

Задля того, щоб виявити ступінь відповідності інформації, яка міститься на найпопулярніших серед вітчизняних аграрників сайтах, зокрема сільськогосподарських підприємств, автор провела короткий екскурс їніми сторінками. Найпершою відвідано інтернет-сторінку fermer.org.ua, розраховану, напевно, на інформаційне обслуговування фермерів. Сайт містить 19 рубрик, зокрема «Новини», «Статті», «Маркетинг», «Технології» тощо. Екскурс сайтом проводився 15 лютого 2017 р. Відкривши рубрику «Новини», бачимо, що остання 3 них датована 13 лютого і стосувалася пропозицій $з$ реалізації посадкового матеріалу та оренди крана маніпулятора. У рубриці «Статті» найновішими чомусь виявилися 10 статей, розміщених на сайті за 12 днів до часу його відвідування. 
Пріоритетні задачі системи інформаційного забезпечення АПК

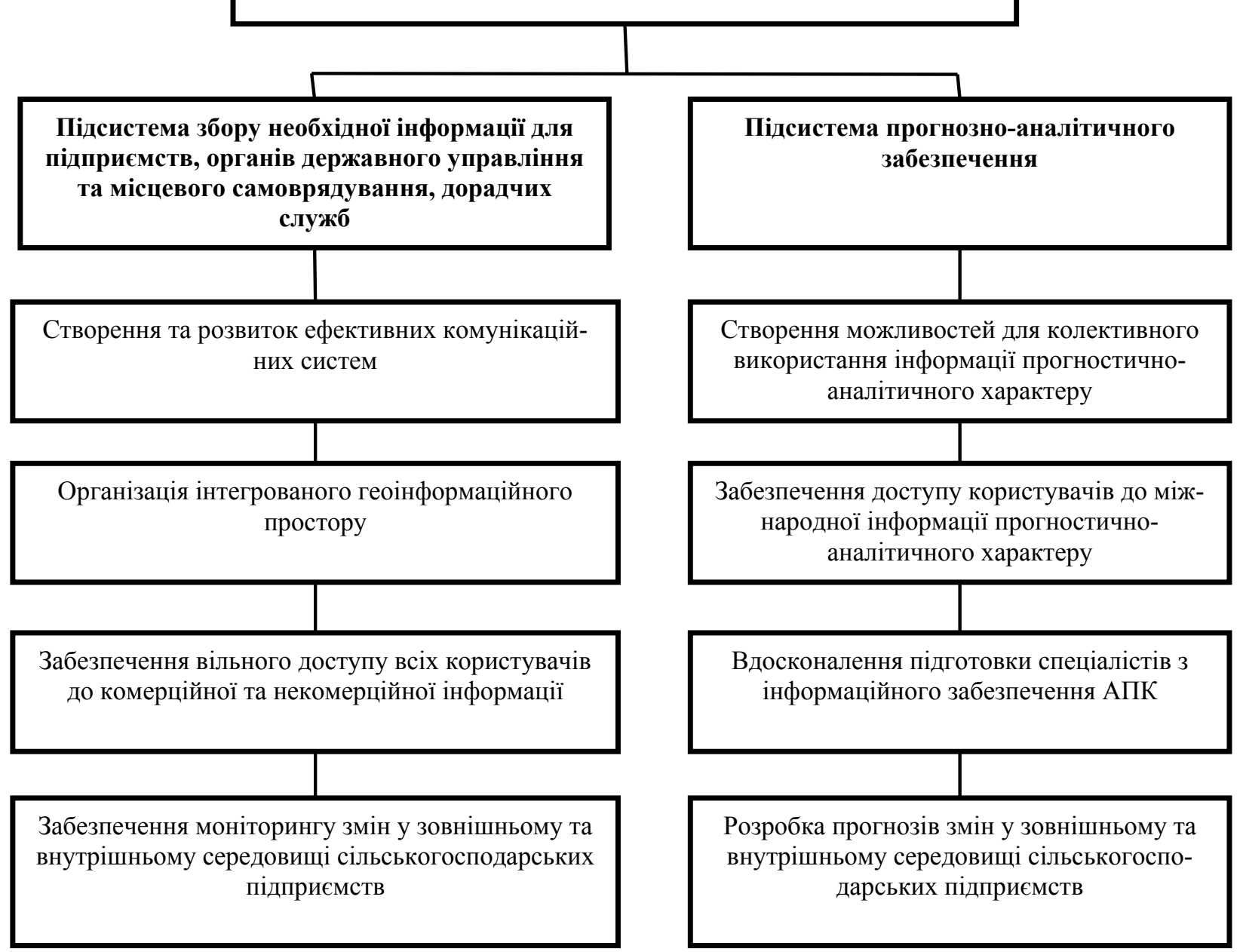

Рис. 1. Пріоритетні задачі системи інформаційного забезпечення АПК*

*Власна розробка автора

Причому всі вони були присвячені одній і тій же тематиці - ігровим автоматам та особливостям окремих видів ігор. Що ж стосується 144 статей, розміщених у рубриці «Технології», найновіша серед них, присвячена помилкам при монтажі та експлуатації електроогорожі, була розміщена ще у квітні 2015 p.

Ще більш застарілими виявилися статті в рубриці «Маркетинг». Висновки про ступінь відповідності цих статей назві рубрики, можна зробити на основі їхніх назв. Характерно, що в перший рік функціонування сайту на ньому виставлялися статті, насправді присвячені проблематиці маркетингу в сільському господарстві, але згодом адміністраторам сайту, очевидно, не вистачило наснаги утримувати планку на належному рівні. Крім усіх інших недоліків цього сайту, варто звернути увагу на його виключну російськомовність і наявність таких статей, як, наприклад, «Молоко - марка Калузької області», «Новий млиновий комплекс ім. С.М. Кірова в Узбекистані» тощо.

Таким чином, на сайті fermer.org.uа розміщена, як правило, застаріла інформація. $Є$ великі претензії до неї також щодо якості. Очевидно, що він не виконує своєї основної функції - стати дієвим помічником фермера в його повсякденних справах. Відвідавши сайт в його теперішньому вигляді, найімовірніше фермер надалі його оминатиме, оскільки він не дає йому відповідей на ті запитання, які щоденно виникають в нього у процесі здійснення господарської діяльності.

Ще гірша ситуація 3 порталом ФЕРМЕРUA/FERMER.UA, створеним для фермерівпочатківців і всіх, хто займається сільським господарством та цікавиться фермерською діяльністю. Серед п’яти його рубрик на середину лютого 2017 р. реально функціонувала лише одна - «Агро-форум», в якій представники окремих підприємств пропонували фермерам певні види матеріально-технічних засобів.

Свого часу НУБіП та УААН широко розрекламували діяльність спільно створеного ними порталу «Аграрний сектор України» (agroua.net). Серед п’ятнадцяти рубрик тут присутня рубрика «Ціни». Однак в ній не наведено жодної цифри. У рубриці «Дорадництво» останні дані наведено за 2006 р. Реально 3 середини грудня 2016 р. портал не функціонував. 
Від названих вище кардинально відрізняються вузькоспеціалізовані агропродовольчі портали PigUA.info та MilkUA.info. Інформація на них подається українською, російською та англійською мовами. Портал PigUA.info містить сім рубрик: «Ціни», «Новини», «Аналітика», «Технології», «Інтерв’ю» та «Оголошення». Дані на порталі оновлюються практично щоденно. Причому інформація, як правило, добирається найактуальніша на певну дату чи за пев- ний період. Так, у рубриці «Ціни» подається як загальна інформація, так і ціни на свиней в Україні та ЄC, а також ціни на племінних, ремонтних та товарних тварин.

Інформація про ціни оновлюється щотижня. Керівники сільськогосподарських підприємств можуть відшукати на порталі багато цінної інформації про годівлю тварин та їх ветеринарне обслуговування, про ринок кормів тощо.

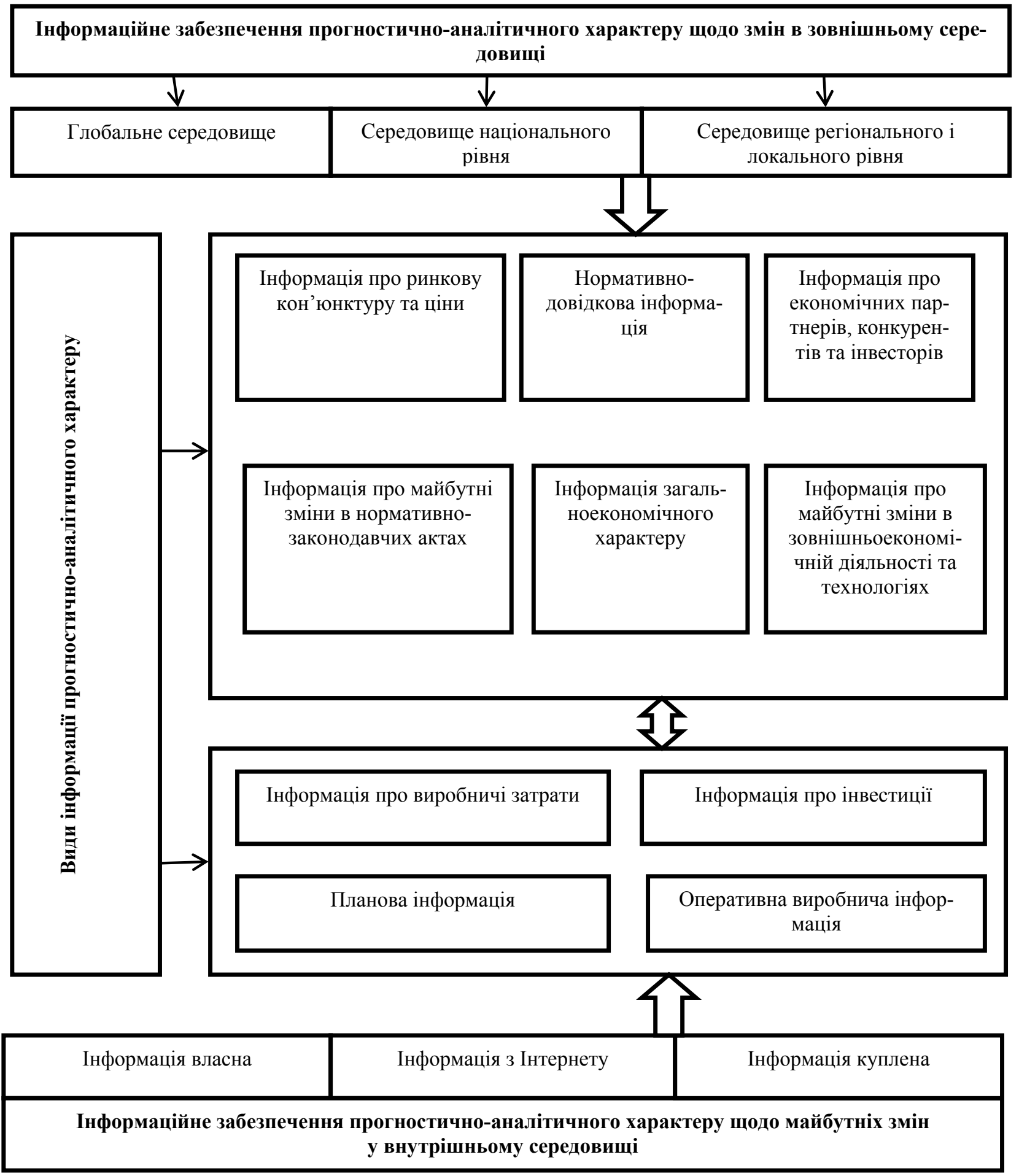

Рис. 2. Основні складові інформаційного забезпечення сільськогосподарських підприсмств прогностично-аналітичного характеру*

*Власна розробка автора 
Водночас надзвичайно бідною $є$ підрубрика «Управління й економіка». До того ж остання інформація на ній виставлена у жовтні 2014 р., хоча екскурс на портал автор здійснювала в середині лютого 2017 р. Загалом обидва названих вище портали вирізняються серед інших високим якісним рівнем, подачею матеріалу у зручній для відвідувача формі.

Формування ефективної системи інформаційного забезпечення сільськогосподарських підприємств, яка дозволить внести значні позитивні зміни в середовище їх функціонування 3 відповідними позитивними змінами в економічній поведінці, неможливе без активної участі в цьому процесі Міністерства аграрної політики та продовольства, Державної служби статистики, вищих навчальних закладів та науководослідних установ аграрного спрямування.

Міністерство аграрної політики та продовольства України, крім виконання інших покладених на нього функцій, повинно активніше долучитися до формування системи інформаційного забезпечення сільськогосподарських підприємств, фермерських та особистих селянських господарств, 3 одного боку, i створення мережі дорадницьких служб, 3 іншого. Однак поки що ця сторона його діяльності відсунута на задній план.

На початкових етапах аграрної реформи в нашій країні передбачалося, що перейнята у спадщину від колишнього СРСР система управління АПК, яка була необхідною для обслуговування потреб плановоцентралізованої економіки, буде трансформована в систему, яка координуватиме діяльність приватних сільськогосподарських підприємств, а основною формою такої координації стане система дорадницькоконсультаційних служб. Проте тисячі, навіть десятки тисяч висококваліфікованих фахівців самого Міністерства, обласних, районних управлінь, а також пов'язаних $з$ ними різноманітних сільськогосподарських служб були звільнені 3 роботи і перейшли до інших сфер зайнятості. У сусідній Польщі їхній інтелектуальний потенціал та виробничий досвід було використано для формування системи сільськогосподарських дорадницько-консультаційних служб, які відіграють помітну роль в інформаційному забезпеченні аграрних підприємств. В Україні, на жаль, цього зроблено не було, але це не означає, що вже в найближчий час таку систему необхідно буде створювати.

Принципово активнішою повинна стати також роль Державної служби статистики в інформаційному забезпеченні аграрних підприємств. На сьогодні ця служба певною мірою виконує функції інформаційного забезпечення центральних та регіональних органів державного управління. Для них готуються відповідні щорічники, аналітичні огляди, щоквартальні та щомісячні звіти та експрес-випуски. На це орієнтовані основні програми статистичних спостережень. Очевидно, що можна висунути значні претензії до структури і якості статистичного матеріалу, який отримують представники органів державного управління, але загалом вони дозволяють отримувати достовірні дані про існуючий розвиток національної економіки, зокрема їі аграрного сектора.

У той же час практично відсутня така складова діяльності Державної служби статистики, як інформаційне забезпечення підприємств, зокрема підприємств АПК. Ця служба як основний осередок збору, нагромадження, обробки й аналізу інформації, як ніяка інша, має можливості забезпечення адаптації цієї інформації до потреб керівників сільськогосподарських підприємств, фермерів, власників особистих селянських господарств. Але для цього необхідні зміни в принципах діяльності цієї служби, програм статистичних спостережень та їх форми. $Є$ надія, що в майбутньому така трансформація діяльності Державної служби статистики неодмінно відбудеться.

Останнім часом значно знизилася роль аграрних вищих навчальних закладів в інформаційному забезпеченні аграрних підприємств. По-перше, вони значно скоротили масштаби наукових досліджень, насамперед у сфері розробки нових технологій виробництва продукції рослинництва i тваринництва; по-друге, фактично зруйнованою виявилася система підвищення кваліфікації та перекваліфікації керівників і спеціалістів сільськогосподарських підприємств та фермерів. Однак саме ці заклади разом із закладами Української академії аграрних наук повинні стати опорними пунктами системного поширення передового досвіду господарювання в сільськогосподарській галузі.

Забезпечення всіх сільськогосподарських товаровиробників комп'ютерною технікою, формування спеціалізованих порталів і мереж, їх програмне забезпечення $є$ лише частиною вирішення проблем. Докорінні зміни в діяльності названих вище установ i організацій необхідне для якісного наповнення цих мереж потрібною підприємцям інформацією. Лише в результаті органічного поєднання технічного та науково-довідкового забезпечення можна створити систему ефективного інформаційного обслуговування.

\section{Висновки}

Ефективне функціонування сучасного інформаційного забезпечення сільськогосподарських підприємств можливе лише в умовах значного поліпшення технологій мобільного зв'язку у країні. Як відомо, кожних 10 років у світі змінюються покоління сотового зв'язку. Кожне наступне покоління відрізняється від попереднього значним зростанням швидкості передачі. Так званий $1 \mathrm{G}$ аналоговий сотовий зв'язок забезпечував швидкість передачі даних до 1,9 Кбіт/с, що дозволяло здійснювати телефонні розмови між абонентами. $2 \mathrm{G}$ цифровий сотовий зв'язок у 90-х роках забезпечував швидкість передачі даних до 14,4 Кбіт/с і дозволяв, крім дзвінків, здійснювати обмін SMS. 3 G широкополосний цифровий сотовий зв'язок досяг швидкості передачі даних до 3,6 Мбіт/с і забезпечував доступ до Інтернету. На даний час в Україні ця технологія активно впроваджується, але доступна лише в найбільших містах країни. Подальше їі поширення стримується проблемами у виділенні необ- 
хідних для зв'язку частот та нестачею фінансових ресурсів у основних операторів мобільного зв'язку.

У розвинутих країнах світу з 2010 р. використовується $4 \mathrm{G}$ зв'язок, який забезпечує швидкість передачі даних до 1,0 Гбіт/с, завдяки чому доступним стає відеострімінг. У 2008 р. розпочалися розробки $5 \mathrm{G}-$ ще швидшого зв'язку (до 20 Гбіт/с), використання якого забезпечить передачу даних в якості Ultra-HD, $3 \mathrm{D}$ - відео, AI - додатки та Інтернет речей.

Впровадження 5 G зв'язку, за оцінками фахівців, розпочнеться у 2018 р. Спершу в країнах з найвищим рівнем IT-технологій. Висока швидкість передачіприйому сигналу дозволить докорінно змінити сучасний стиль життя людей. Розвинеться Інтернет речей $з$ дистанційним управлінням їхніми функціями. Докорінно зміниться процес навчання, здобуття освіти, способи спілкування між людьми, з'являться безпілотні автомобілі, об'єктивна реальність доповнюватиметься віртуальною в усіх сферах людського життя.

Впровадження 5 G зв'язку призведе до революційних змін у бізнес-процесах. У сільському господарстві стане можливим широке використання дронів, роботів, запровадження онлайн-моніторингу полів та тварин, про що писалося вище.

Усі попередні покоління сотового зв'язку не могли забезпечити управління великою кількістю технічних засобів у зв'язку із низькою швидкістю передачі інформації. Технологія $5 \mathrm{G}$ дозволить успішно реалізувати ті зміни у внутрішньому i зовнішньому середовищі сільськогосподарських підприємств, які зможуть забезпечити їхню конкурентоспроможність у мінливому світі.

На жаль, в Україні до впровадження 5 G зв'язку ще надто далеко. Кабінет Міністрів у листопада 2016 р. затвердив детальний план переходу на 4 G зв'язок. Низка передбачених ними заходів розрахована до 2020 р. На цей час провідні мобільні оператори задекларували запуск мереж п'ятого покоління до зимових Олімпійських ігор у Південній Кореї (2018р.), чемпіонату світу з футболу в Росії (2018 р.), літніх Олімпійських ігор в Японії (2020р.). Щоб безнадійно не відстати в цій сфері, уряду країни, провідним операторам мобільного зв'язку слід виробити реальну програму прискореного запуску 5 G зв'язку.

Упровадження $5 \mathrm{G}$ зв'язку, використання його можливостей для докорінних змін у виробничих процесах i технологіях в сільськогосподарських підприємствах вимагають величезних коштів. Йдеться про мільярди доларів інвестицій. Для цього необхідне значне покращення у сфері партнерства влади й бізнесу, позитивні зміни в інвестиційному кліматі у країні.

Удосконалення інформаційного забезпечення сільськогосподарських підприємств необхідне для підтримання їхньої конкурентоспроможності на національному та світовому агропродовольчих ринках. Неминуче запроваджуватимуться нові технології виробництва продукції рослинництва і тваринництва, нові стандарти іiї якості та властивостей. Сільськогосподарські підприємства адаптовуватимуться до цих змін, на що спрямовуватиметься їх видозмінена економічна поведінка.

\section{Бібліографічні посилання}

Dyakova, T.A. (2017). Informacijne zabezpechennya upravlinnya ekonomichnoyu stijkistyu silskogospodarskych pidpryyemstv. Rezhy`m dostupu: https://www.pdaa.edu.ua/sites/default/files/nppdaa/5.1 /83.pdf (in Ukrainian).

Lapin, A.V. (2015). Informacijne zabezpechennya vertykalnoyi integraciyi pidpryyemstv agrarnogo sektora: avtoref. dys. na zdobuttya nauk. stupenya kand. ekon. nauk: specz. 08.01.04. Zhytomyr, 20 (in Ukrainian).

Ukray`nskoe selskoe chozyajstvo v style smart. Rezhym dostupu:

http://agroportal.ua/ru/publishing/sobytiya/ukrainskoe -selskoe-khozyaistvo-v-stile-smart (in Russian).

Strategiya rozvytku informacijnogo zabezpechennya APK i silskogo naselennya Ukrayiny do 2015 roku, rozroblena fachivcyamy Ministerstva. Rezhym dostupu: http://studyes.com.ua/raznoe/strateg-yarozvitku-nformats-ynogo-zabezpechennya- apk-slskogo-naselennya-ukra-ni-do-2015-roku.html (in Ukrainian).

Kharchenko, V.V., Onyshchuk, V.R. (2013). Do pytannia informatsiinoho zabezpechennia upravlinnia ahrarnoho pidpryiemnytstva. Innovatsiina ekonomika. 5, 332-336 (in Ukrainian).

Shvy'denko, O.M. (2013). Osoblyvosti zastosuvannya internet-marketyngu $\mathrm{v}$ silskomu gospodarstvi SshA. Agroinkom. 4-6, 11-16 (in Ukrainian).

Received 1.09.2017

Received in revised form 29.09.2017 Accepted 4.10.2017 